\title{
The Role of Social and Institutional Contexts in Social Innovations of Spanish Academic Spinoffs
}

\author{
Noelia Franco-Leal ${ }^{1}{ }^{*}$, Carmen Camelo-Ordaz ${ }^{1}$, Juan Pablo Dianez-Gonzalez ${ }^{1}$ and \\ Elena Sousa-Ginel ${ }^{2}$ \\ 1 Business Administration, University of Cadiz, 11002 Cadiz, Spain; maricarmen.camelo@uca.es (C.C.-O.); \\ juanpablo.dianez@uca.es (J.P.D.-G.) \\ 2 Business Administration and Marketing, University of Pablo de Olavide, 41013 Sevilla, Spain; \\ esougin@upo.es \\ * Correspondence: noelia.franco@uca.es
}

Received: 8 January 2020; Accepted: 24 January 2020; Published: 26 January 2020

\begin{abstract}
Social innovations developed by academic spinoffs (ASOs) are acquiring an ever-increasing relevance in the literature on academic entrepreneurship. Previous studies have considered the importance of the social and institutional contexts of entrepreneurial ecosystems for the development of these innovations, although a greater depth of analysis is required in this field of study. This research analyzes the influence of the frequency of contact with agents of social and institutional contexts of the entrepreneurial ecosystem on the social innovations of ASOs. From a sample of 173 Spanish ASOs, the results indicate that frequent contact with government and academic support units improves this type of innovation of ASOs. Regarding social context, an increase in the frequency of contact with customers, suppliers, and competitors favors the development of social innovation. However, frequent contact with venture capital firms inhibits the development of this type of innovation.
\end{abstract}

Keywords: academic spinoffs; social innovation; entrepreneurial ecosystem; social context; institutional context

\section{Introduction}

Recent studies within the literature on academic entrepreneurship highlight that academic spinoffs (ASOs) should constitute a focal point for academics and policy-makers, not only because they contribute towards economic renewal, industrial and regional change, and the economic development of emerging markets [1,2], but also due to the social impact that the commercialization of their knowledge bases may provide [3,4]. In this respect, several studies emphasize the role of ASOs in the development of social innovations from a sustainable perspective, and also the influence that universities may have in promoting mechanisms that support the creation and development of said innovations [3-8]. Scholten and van der Duin [3] argue that ASOs often develop radical innovations that translate into new business models, alternative products, and approaches of a more sustainable nature that respond to social problems and demands. For their part, Fini et al. [4] consider that universities and academic entrepreneurs tend to be motivated more toward the creation of knowledge that responds to the great challenges of society than towards obtaining economic income from the commercialization of such knowledge.

Despite the major role that ASOs should play in social innovation, the lack of critical resources and capabilities that characterize these firms, mainly in the form of funding, commercial and productive knowledge, and entrepreneurial and managerial skills, may inhibit the successful development of these innovations [9]. Given this circumstance, the entrepreneurial ecosystems of ASOs play a critical role in providing them with the access to the resources and capacities they need for the development of 
social innovations $[10,11]$. Specifically, several studies point out that among the various contexts that comprise the entrepreneurial ecosystem, the social and institutional contexts acquire special relevance since they allow ASOs to gain access to critical resources and capacities for social innovation $[4,9]$. Thus, from the social context, ASOs access knowledge regarding existing or latent social needs and how to meet such needs $[12,13]$. The institutional context provides ASOs with information on specific fiscal regimes, public financial resources, and managerial and entrepreneurial skills [11,14,15]. Therefore, the analysis of how social and institutional contexts of the entrepreneurial ecosystem can support the development of social innovations of ASOs constitutes a major research topic [9].

A review of the literature on entrepreneurial ecosystems and social innovation in the field of entrepreneurship reveals that studies analyzing how entrepreneurial ecosystems can support the companies that develop social innovation through the supply of resources remain scarce and are mainly theoretical or are based on case studies [14-16]. Furthermore, the majority of these studies have considered entrepreneurial ecosystems as a single construct, without a specific analysis of the impact that can be exercised by each of the contexts that comprise it: institutional, social, organizational, and industrial and technological contexts [17]. In line with this argument, De Bruin et al. [18] established that there is a gap in the literature regarding the recognition of the "multiplicity of contexts" of the entrepreneurial ecosystem for the successful development of social innovations. In this same respect, Alvedalen and Boschma [19] and Autio et al. [17] highlighted that one of the challenges in this field of research involves the development of quantitative empirical evidence that links the various contexts of the entrepreneurial ecosystem with different performance measures in order to ascertain the effectiveness of the ecosystem.

On the other hand, within the academic entrepreneurship literature, social innovation has barely been studied, and research linking social innovation and entrepreneurial ecosystem is even scarcer. However, several authors theoretically argue the importance of universities and governments for the development of sustainable social innovations of ASOs [4-9] and claim that more research is required into the effectiveness of the entrepreneurial ecosystem on the entrepreneurial outcomes of ASOs from a social perspective.

Therefore, while taking into account the literature on entrepreneurial ecosystems, network structure, social innovation, and academic entrepreneurship, this study analyzes the effects that the social and institutional contexts of the entrepreneurial ecosystem exert on the social innovation of ASOs. In our research, in order to consider the idiosyncratic characteristics of the academic entrepreneurship context, the institutional context is assumed to comprise actors from both the university context (e.g., technology transfer offices (TTOs), university incubators, research colleagues, chairs of entrepreneurs, and research centers) and from the non-university context, in form of mainly government and institutions. For their part, within the social context of the entrepreneurial ecosystem, customers, suppliers, competitors, and venture capital firms (VCs) are included [20]. Specifically, our research questions are: What agents from the social and institutional contexts of the entrepreneurial ecosystem contribute towards improving the social innovation of ASOs?; Which of these contexts, social or institutional, is more relevant for the social innovation of ASOs? To answer these research questions, a sample of 173 Spanish ASOs originating from public universities and created in the period 2003-2018 was used. Using linear regression models, the effects of the frequency of contact as a measure of the relationship with various agents from the institutional and social contexts on the social innovation of ASOs are analyzed.

The most important contributions of this study are as follows. On the one hand, contributions to the entrepreneurial ecosystem literature are made in two ways. First, we respond to a demand in the recent literature that calls for more research linking the entrepreneurial ecosystem and the innovation performance of entrepreneurial firms in order to ascertain the effectiveness of the entrepreneurial ecosystem $[19,21,22]$. Moreover, as laid out in the literature, we recognize the "multiplicity of contexts" of the entrepreneurial ecosystem [18] and focus on the effects of two specific contexts instead of the entrepreneurial ecosystem as a whole. Second, the relationship with the agents of the ecosystem is 
analyzed from a network structure perspective. In this regard, Alvedalen and Boschma [19] proposed a challenge for the literature on entrepreneurial ecosystems: It should consider certain structural elements of networks, such as the frequency of contact, in order to analyze whether specific structural patterns of relationships with different agents from different contexts may favor or inhibit the influence of the ecosystems on the innovations of firms. On the other hand, our study contributes to the academic entrepreneurship literature, since it constitutes the first attempt to analyze the antecedents of social innovations of ASOs from an entrepreneurial ecosystem approach. Recent studies demand further research into external agents that can promote and support the social innovations of ASOs $[4,7,9]$. These firms provide the main source of knowledge transfer in Europe and stand at the threshold of solving the major challenges of society [3,4]. Policy-makers are therefore interested in ascertaining how the entrepreneurial ecosystem promotes the successful commercialization of such knowledge. However, to date, no research on this topic has yet been produced.

\section{The Entrepreneurial Ecosystem and Social Innovation in Academic Spin-Offs}

The entrepreneurial ecosystem literature has its origins in the 1980s and 1990s, when several researchers highlighted the impact that regional, international, social, cultural, political, and economic contexts exert on the entrepreneurship process and on the results derived from this process [23-25]. A generally accepted definition of an entrepreneurial ecosystem is provided by Stam [26] (p. 5), who stated that the entrepreneurial ecosystem refers to "a set of interdependent actors and factors coordinated in such a way that they enable productive entrepreneurship".

From existing studies, four starting premises of entrepreneurial ecosystem theory can be derived. A first premise is that the entrepreneur must have a proactive role in the development and maintenance of links with different actors within the entrepreneurial ecosystem [27]. The second premise states that through the agents that comprise the entrepreneurial ecosystem, entrepreneurs can access various types of resources (such as funding, and market and technological knowledge, among others) and/or capabilities related to management, production, and marketing [28]. A third premise recognizes the multiplicity of the contexts within the entrepreneurial ecosystem [21]. In this respect, Autio et al. [21] proposed that the actors and factors that comprise the entrepreneurial ecosystem can be grouped into four different contexts: institutional, social, industrial and technological, and organizational. The institutional context refers to relationships with governments, universities, science parks, accelerators, incubators, and suchlike, which support the innovation of companies through financing, advice or training activities [21,27]. The social context is formed by industrial actors, such as customers, suppliers, competitors, VCs, and business angels. These actors support entrepreneurs through access to risk capital, talented workers, commercialization resources, and production capabilities [21,27]. The industrial and technological context comprises the industry lifecycle, and types of products or technologies, among other aspects [21]. These characteristics of industry and technology determine the facilities or difficulties in obtaining critical resources, thereby improving or inhibiting innovation. Finally, the organizational context refers to the specific factors of an organization, such as its own capabilities, resources, and experiences, which may affect a firm's ability to obtain a better position from which to access other key resources in order to improve its innovation outcomes. A fourth premise is that the contexts of the entrepreneurial ecosystem affect the innovation performance of companies in various ways, and therefore, depending on the types of innovation developed by the firms, the companies will need to rely on different contexts of entrepreneurial ecosystem [21].

Social innovation is gaining great attention in recent literature $[11,14,18]$. This phenomenon has its origins in 1972, when Banks proposed that social demands can be resolved through management practices. At present, social innovation is considered as the 'sixth wave' of macrolevel change and has the potential to be as disruptive and influential as the industrial revolution or the age of information and telecommunications [29]. It was in Europe in 1990 when the rise of research on this topic began, exponentially increasing its relevance at the beginning of 2000 [11,30,31]. This proliferation of studies 
has brought with it a multitude of definitions that have several elements in common but also differ significantly [32], in such a way that the term social innovation seems to mean different things to different authors [33]. In a strict sense, social innovation is defined as those "innovative activities and services that are motivated by the goal of meeting a social need and that are predominantly diffused through organizations whose primary purposes are social" [34] (p. 146). Similarly, Phills et al. [35] (p. 39) defined social innovation as "a novel solution to a social problem that is more effective, efficient, sustainable, or just than existing solutions and for which the value created accrues primarily to society as a whole rather than private individuals". Two key figures of social innovation can be derived from these definitions. First, social innovations originate from the intention to meet a social need or to try to solve a social problem, promoting social progress and prosperity $[5,36,37]$. Second, social innovations are diffused by organizations with a social purpose and tend to be located in the so-called "third sector", which consists of nongovernmental and nonprofit organizations [38]. From this point of view, social innovations are distinctive from business innovations, which are driven by profit maximization and diffused through organizations that are primarily motivated by profit outcomes [34].

However, a broader perspective exists in the literature, which expands the meaning of social innovation in two directions $[39,40]$. On the one hand, it is possible to find definitions of social innovation that refer either to the intention of the innovator or to the wider social consequences of the innovation beyond the confines of the innovating organization. Therefore, an innovation may be termed "social" if it produces good consequences that benefit a wide range of stakeholders in the society, although it is not motivated at root by the intention to solve a social problem [32]. In this vein, Adams et al. [41] considers that the term "social" refers to the notion of sustainability-oriented innovations in which economic, social, and environmental considerations are integrated. On the other hand, it is argued that social innovations are not limited to the nonprofit sector and may be initiated and diffused everywhere in the economy, including the public and private sectors [38]. Moreover, Nicholls and Murdock [29] consider that social innovations usually happen in the boundaries between the public, private, and nonprofit sectors, as a product of the contradictions and tensions between them.

Therefore, there is no specific privileged type of organization capable of developing social innovation, but a plurality of organizations thereof [42]. According to this perspective, social innovation and business innovation are not exclusive concepts but instead show considerable overlap [43], in that every innovation has a financial as well as a social impact, whether intended or otherwise [38]. Therefore, the literature on social innovation faces the challenge of pursuing a better alignment of business performance goals with the attainment of wider societal objectives [32,44]. In this respect, Tekula et al. [8] argued that social enterprises are typically hybrid organizations with for profit and nonprofit aims, searching a balance between social and economic value creation.

This study focuses on this broader perspective, and, following Martínez et al. [32], considers that it is more useful to define "social" and "business" as dimensions of all innovations, rather than trying to draw a line between the two. Therefore, every innovation can be more or less social, and more or less business. On the other hand, following Murray et al. [45] (p. 5), in this study, social innovation "refers not to any particular sector of the economy, but to innovation in the creation of social outputs and outcomes regardless of where they spring from".

Within academic entrepreneurship literature, recent studies are emphasizing the relevant role that universities may have in developing and promoting mechanisms that support the creation and development of social innovation and sustainable entrepreneurship [3-7,37]. In line with this argument, Tiemann et al. [46] argued that universities have internalized a third central role aimed at developing and supporting innovations oriented towards social challenges. ASOs constitutes one of the main mechanisms used by universities to promote and develop social innovations. These firms are located in the boundaries between private and public initiatives, where social innovations often happen as a product of the tensions between private, public, and nonprofit sectors, as we stated previously [29].

The analysis of social impacts of outcomes of science commercialization by the ASOs raises several relevant issues that should be addressed: first, the motivation and orientation of these companies to 
seek the social impact in the commercialization of their scientific knowledge; and second, the analysis of the role played by the entrepreneurial ecosystem in which these companies are immersed as enablers for the development of social innovations.

With respect to the first question, academics may vary widely in their motivation for engaging in commercial activities [47], but they are more willing to contribute to these processes when they see science commercialization as a tool for creating impacts from research rather than primarily for short-term business. ASOs are therefore particularly well suited to bring together the commercial and noncommercial partners and resources needed to look beyond immediate financial rewards in order to tackle major societal problems through a market-based approach [48]. Supporting this argument, Lundström and Zhou [5] argued that scholars engage in academic entrepreneurship activities motivated by solving the needs of society and creating social value from their knowledge and technologies bases. These ASOs' technology bases are usually new and disruptive, being at the frontiers of knowledge. Therefore, its application in solving the great societal problems, mainly climate change and health, is more effective. In this regard, although some authors consider that social innovations can occur in different types of technologies of any industry, Maiolini et al. [49] stated that social innovations usually appear when technologies or disruptive knowledge are exploited. On the other hand, another relevant argument that justifies the social commitment of ASOs is that, given that these companies are usually publicly funded, this investment is expected to make a return to society in the form of solving social problems from a sustainability point of view [4]. In recent years, national and international governments have become aware of the need to finance entrepreneurship activities derived from universities that are addressed to achieving sustainable economic growth and solving fundamental challenges such as climate change, biodiversity loss, and water scarcity $[8,46]$. In this vein, the commercialization of the knowledge bases of ASOs stands at the forefront for policy-makers of the European Union, as may be reflected in the United Nations' social development goals and in the Europe Union's program Horizon $2020[4,6]$. Therefore, understanding the factors that facilitate the transfer of ASOs' scientific knowledge into practical applications with a significant positive impact on society constitutes the key for reaping the benefits from public investments in scientific research. Indeed, accordingly, universities are increasingly aware of the need to include aspects related to sustainability in their training plans in order to educate future social entrepreneurs, which is reflected in their strategic plans' priority areas related to corporate social responsibility and financing the creation of firms aimed at developing social innovations [37]. Moreover, universities are providing appropriate systems and infrastructures to guide academic entrepreneurs toward the commercialization of science and technology from a social and sustainable perspective [46]. In line with this argument, Tekula et al. [8] found that universities are creating specific centers to support entrepreneurial initiatives developed by students and researchers, addressed at solving social problems from a sustainability perspective. Therefore, universities may play a pivotal role within the entrepreneurial ecosystem in promoting sustainability principles and thus contribute to the paradigm shift toward more sustainable development through ASOs [50]. As Tiemann et al. [46] (p. 88) stated, university support for sustainable entrepreneurship and the development of social innovation "is relevant to help students, researchers, and university teachers develop their entrepreneurial skills and start new ventures, and to help external economic actors develop and establish green products and sustainable business models".

Bearing this in mind, we consider that ASOs are especially well-suited to analyzing social innovation because, although these firms are created to commercially exploit scientific knowledge that is not necessarily directed at meeting a social need, they are increasingly recognized for their positive impact on society, and their contribution to job creation, regional development, and to the improvement of the quality of life in general $[4,51]$. Therefore, with the term social innovation of ASOs, we refer to the social, cultural, environmental, and economic returns (impact and effects) from new or improved products or services based on publicly funded academic research $[4,51]$.

Considering the capacity of ASOs to develop social innovations, it is necessary to point out that the development of social innovation acquires great complexity, since companies cannot rely on their 
own internal, but rather they must connect their knowledge bases with external knowledge regarding existing or latent social demands or problems. Hence, these innovations do not occur within a vacuum, but within an entrepreneurial ecosystem [10,52]. Within this entrepreneurial ecosystem, recent studies grant major importance to the social and institutional contexts, because these can provide access to the various types of knowledge that these firms need for the development of social innovations through a process of co-creation [10-14,18]. With respect to the institutional context, Melane-Lavado and Álvarez-Herranz [13] found that universities can provide knowledge regarding unsatisfied social demands and regarding how to meet these demands from a sustainability point of view. Considering the social context, on the one hand, firms may rely on relationships with customers to access highly specialized market knowledge on the existing or latent needs of society [12]. On the other hand, firms may co-create with their competitors in order to develop innovations focused on social products and services [12]. Finally, suppliers may provide information on raw materials and inputs that firms can use in their production processes to reduce resource intensity, emissions, and waste in order to render social innovations more sustainable [13].

In addition to this knowledge, the literature has highlighted access to other key resources for the development of social innovations, mainly in terms of funding and managerial and entrepreneurial skills $[11,14,15]$. These resources can be obtained from agents from an institutional context. On the one hand, funding may be provided by governmental institutions, through grants, subsidies, incentives, etc. $[15,53]$. On the other hand, academic support units often supply knowledge and skills related to the creation and development of financially sustainable social business models [14,54]. In short, as previously established in the fourth premise of the literature on entrepreneurial ecosystems, only certain specific agents of the entrepreneurial ecosystem will favor the development of these innovations, through the supply of these resources.

In order to access these resources, companies must focus their efforts on maintaining frequent contact with the aforementioned agents of the entrepreneurial ecosystem [55]. The development of social innovations implies a complex process of co-creation with multiple agents, in which companies must identify, assimilate, and apply the new knowledge acquired, which tends to be highly tacit. It would therefore be necessary for these companies to maintain frequent contact with the agents of their ecosystems, since frequent contact increases the development of a shared understanding and common routines or ways of working together, leading to a more effective acquisition and integration of high-quality and tacit knowledge [56-61]. With respect to the resources needed for social innovations that are not tacit, such as funding, the frequency of contact is also relevant, since it increases trust and the number of shared experiences, which in turn induce agents to be more inclined to support these companies [55].

Within the academic entrepreneurship literature, other authors also recognize that entrepreneurial ecosystems can provide ASOs with different types of resources that they need for their creation and for the improvement of their performance [4,20,62-64]. However, to the best of our knowledge, no studies have yet considered the link between agents of the entrepreneurial ecosystem and social innovation of ASOs [4,9].

Therefore, based on all the aforementioned arguments, our baseline hypothesis is that frequent contact with agents from the social and institutional context of the entrepreneurial ecosystem could facilitate the access to critical resources that ASOs need for the development of social innovations.

\section{Development of the Hypotheses}

\subsection{Social Context of the Entrepreneurial Ecosystem}

Relationships with suppliers, customers, and competitors may play a critical role in improving social innovation of ASOs, since they provide a direct source of various types of knowledge related to existing and latent social problems that is necessary for the development of social innovations through a process of co-creation $[12,13]$. 
The process of co-creation for social innovations is highly complex due to three main reasons [65]. First, this process implies the identification and transfer of knowledge regarding social problems, which usually present a high level of tacitness, and therefore, it is difficult to share and assimilate [55]. Second, the cultural distance that exists between ASOs and the agents from the social context increases the complexity of these co-creation processes, since these firms may face obstacles in understanding the knowledge provided by these agents [66,67]. Finally, since this is a co-creation process, it is necessary that the transferred knowledge be integrated with the knowledge bases of the ASOs. The ASOs usually have a knowledge base characterized as being highly tacit, and it would therefore be more problematic for these firms to explain said knowledge to agents from social contexts [68], since it is more difficult for these agents to understand how the potential applications of ASO knowledge bases can respond to social demands. Therefore, these companies face difficulties in both identifying and assimilating tacit external knowledge about social demands and in integrating it with their knowledge base, which is also tacit.

Given these circumstances, it would be necessary to have suitable mechanisms to identify, transfer, and integrate this tacit knowledge with the knowledge bases of the ASOs in order to develop social innovations. One mechanism that could favor these processes is the frequency of contact with agents from the social context. Prior research considers that this structural element increases both the development of shared understanding and an overlap of the knowledge bases between the parties involved in the relationship, which in turn lead to a more effective acquisition and transfer of external tacit knowledge, and the suitable integration of this knowledge with knowledge bases that are also tacit $[57,58]$. Therefore, through increasing the frequency of contact with social agents, ASOs could improve the process of co-creation of social innovations.

Based on these arguments, we establish our first hypothesis:

Hypothesis 1: The frequency of contact with customers, suppliers, and competitors from a social context is positively related to social innovations of ASOs.

Another agent of the social context that could affect the development of social innovations of ASOs is the VC. The literature on social innovation highlights that these investors are not usually interested in financing companies that pursue social objectives [69,70]. In this respect, VCs tend to prioritize strictly financial returns from their investments, and hence, companies pursuing social objectives are not aligned with the objectives of the VCs [14]. Based on this argument, if the innovations of the ASOs have a social objective, then they could experience serious difficulties in accessing financing from VCs. However, this type of financing is highly relevant for ASOs, since obtaining venture capital also implies access to market credibility and managerial competences, which they often lack [71-73]. In order to obtain these resources, ASOs often increase the frequency of contact with VCs. However, the increase in the frequency of contact can yield a contrary effect, since VCs would transmit a purely financial business orientation to ASOs. As a consequence, an exoisomorphism, that is, an alignment of objectives of ASOs with VC norms, could happen [74]. Supporting this argument, Souitaris et al. [74] argued that in order to access financial resources from VCs, firms should align their own objectives with the financial objectives of VCs. Therefore, the frequency of contact with VCs could inhibit the development of innovations that seek sustainable solutions to social problems and demands.

From these arguments, we derive the following hypothesis:

Hypothesis 2: The frequency of contact with VCs from a social context is negatively related to social innovations of ASOs.

\subsection{Institutional Context of the Entrepreneurial Ecosystem}

Within the institutional context, the actors can derive social innovations from both a non-university setting and a university setting [21]. 
The most relevant non-university contacts for the development of social innovations are governmental institutions [75,76]. From the review of 102 scientific articles, Bozhikin et al. [76] concluded that government is a major player in the process of promoting social entrepreneurship and, as a result, social innovation. According to these authors, governments use various mechanisms to stimulate social entrepreneurship. Firstly, governments may design and create different legal and fiscal frameworks to promote social innovations [77]. This legal and fiscal framework to protect and stimulate firms that develop social innovations [78,79] is materialized through mechanisms such as laws, decrees, and directives and taxes. In this vein, Griffiths et al. [79] argued that government institutions could support the development of firms that concentrate on social innovations by promoting fiscal policies that focus on reducing the particular taxes and fees for these firms [79]. Secondly, firms that innovate socially are usually provided with public financial resources by government institutions [11,14,75,80-82]. Bozhikin et al. [76] pointed out that financial support could be given in the form of subsidies and funding (e.g., funding for environmental protection grants or for the development of social entrepreneurship in universities). Specific funding for universities as a public institution constitutes a direct incentive necessary for the development of social innovation from scientific discoveries by ASOs. Several studies carried out in Europe find that the development of organizations with social purposes depends highly on projects funded by governments, since the initial returns of these firms are very limited [83]. Thirdly, Bozhikin et al. [76] (p.741) stated that "teaching and training social entrepreneurs and their workers can also be the key priority of governments, especially for public universities". Thus, government support through training programs and advice for social entrepreneurship in universities may stimulate the transfer of scientific discoveries into the development of a social function. Finally, government institutions may offer partnerships to firms in order to jointly develop social innovations [76], by acting as mediating agents that facilitate the co-creation process necessary for social innovation. The benefits of these joint activities are not only derived from the possibility that these agents may provide ASOs with specific information regarding social demands and problems, but also that these firms can use public in-kind resources, such as professional skills and equipment, necessary for the development of social innovations $[75,79]$. In order to achieve not only an effective transfer of public financial resources, but also greater knowledge of fiscal and regulatory policies and an involvement of institutional agents in the co-creation process of social innovations, ASOs should increase the frequency of contact with these agents.

As for agents from a university context, they may play a critical role in promoting the social innovations of ASOs. Recent research argues that European universities are increasingly aware of how to solve the major problems and demands of society from a sustainable point of view $[83,84]$. This increasing awareness towards sustainability is reflected in their strategic plans that include new goals, visions, and priority areas related to corporate social responsibility [7]. By taking these strategic plans as a reference, universities integrate this social and sustainable culture within the university community through their teaching, research, and entrepreneurship activities and nurture ASOs with this culture [85,86]. In this respect, Fitcher and Tiemann [7] found that universities include specific aspects related to sustainability and solutions to social problems within their teaching programs and are interested in designing funding programs to support research projects linked to corporate social responsibility. With regard to entrepreneurship activities, these authors demonstrated that universities, through their support infrastructures, such as incubators, research institutes, research centers, and TTOs, guide academic entrepreneurs towards the commercialization of science and technology from a social and sustainable perspective [7]. In this way, an isomorphism with the university could occur, since the ASOs would align the objectives of their innovations with those of their universities of origin, thereby adopting the values and sustainable standards of their universities as their own [87]. The adoption of this mindset will help ASOs to identify social and sustainable business opportunities [7].

On the other hand, university support units may positively affect the development of social innovation in ASOs, since one of their main functions involves the supply of a network of relationships with actors from the social context $[19,86]$. ASOs face external and internal liabilities of newness and 
smallness [88], which makes it difficult to attract social agents. University support units help ASOs to overcome this challenge [86]. Thus, TTOs develop and maintain networks with industry agents, such as suppliers, customers, and competitors, which are highly relevant because they constitute the direct source of knowledge regarding the demands and the problems of society [12,13]. In short, university support units help ASOs to contact agents from a social context, which facilitates access to the information and resources needed for the development of social innovations. On the other hand, in a similar way to government institutions, university support units may facilitate partnerships with social agents in order to jointly develop social innovations [75] through the necessary co-creation process.

Based on these arguments, the following hypothesis is established:

Hypothesis 3: The frequency of contact with agents from the institutional context (university and non-university) is positively related to social innovations of ASOs.

\section{Methodological Framework}

Figure 1 contains a descriptive flowchart of our proposed methodological framework. The sequential steps of our methodology are described below.

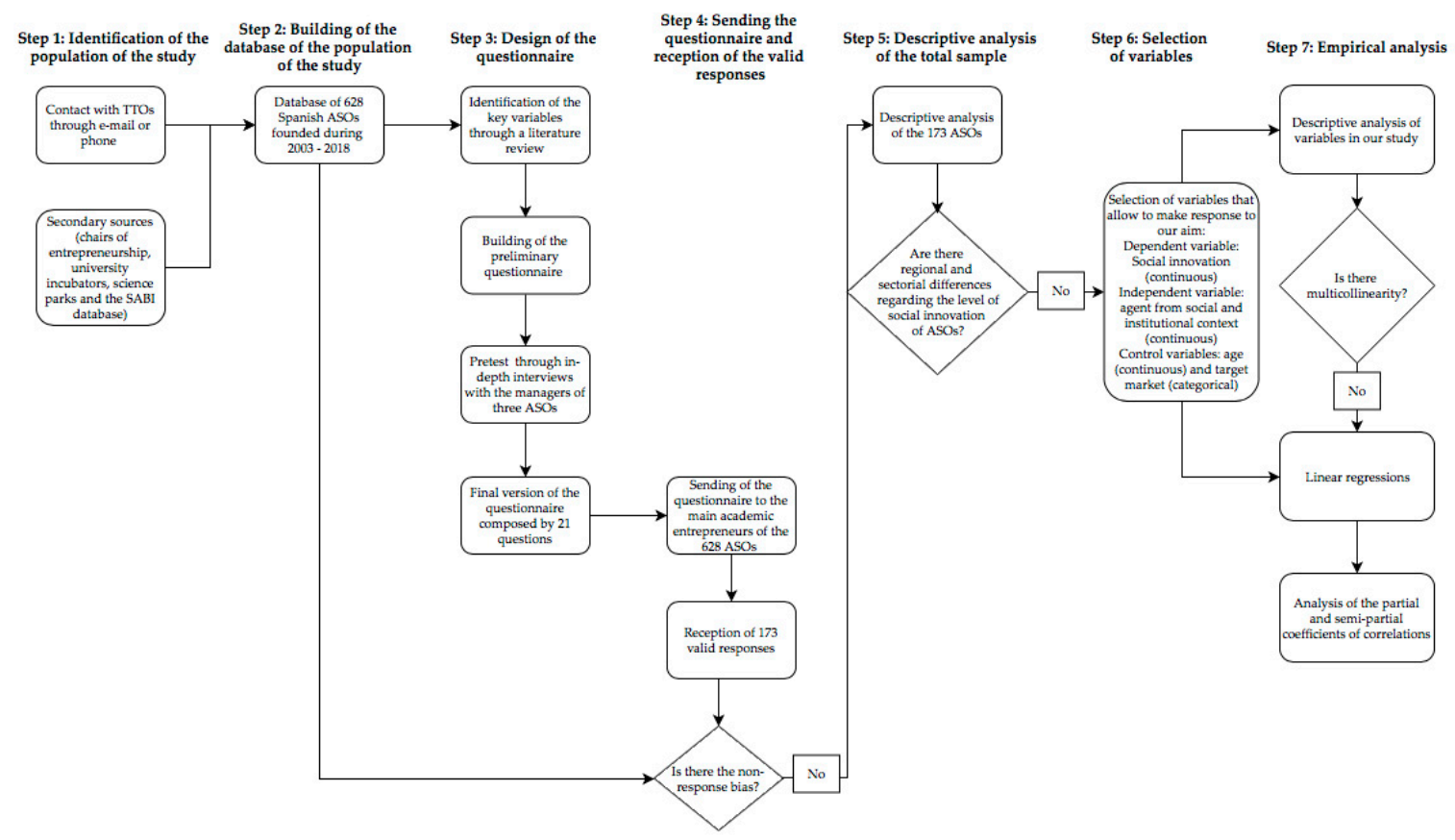

Figure 1. Descriptive flowchart of the methodological framework.

Step 1: Identification of the Population of the Study

Since no database with information on all the Spanish ASOs exists, it was necessary for such a database to be built. Thus, in order to identify the companies included in the population, a formal request for collaboration was sent via email to the managers of 70 Spanish Technology Transfer Offices (TTOs). For those cases in which the TTO staff failed to respond to a request by email, they were also contacted by phone. Moreover, to complete the information provided by the TTOs regarding the ASOs, a set of secondary sources were used, such as annual reports developed by the chairs of entrepreneurship, university incubators, science parks, and the Iberian Balance Sheet Analysis System (Sistema de Análisis de Balances Ibéricos, SABI).

Step 2: Building the Database of the Population of the Study

From the information gathered in the previous step, an original database of 628 Spanish ASOs founded during 2003-2018 was created. For each ASO, the following information was collected: phone 
number, email address, web site, company name, founder name, year of constitution, industry, research group, and the identification of the leader of each research group.

Step 3: Design of the Questionnaire

Subsequently, an exhaustive literature review was generated in order to identify key variables and their measurements. From this literature review, a preliminary questionnaire was designed that was pretested through in-depth interviews with the academic entrepreneurs and managers of three ASOs in 2018, and their recommendations were considered. The final version of the questionnaire was composed of 21 questions.

Step 4: Sending of the Questionnaire and Reception of the Valid Responses

The final version of the questionnaire was sent via email to the main academic entrepreneur of each of the 628 ASOs in our database. Those academic entrepreneurs who failed to respond the questionnaire by email were contacted by phone. Considering these ASOs and those that participated in the pretest, our sample consisted of 173 established ASOs (response rate: 27.6\%).

In order to ascertain whether there were mean differences between the respondent and nonrespondent ASOs in our database, the nonresponse bias was analyzed. To this end, a $t$-test was applied on independent samples for the comparison of respondent and nonrespondent ASOs regarding age and size (number of employees). From these results, it could be demonstrated that there were no mean differences between the respondent and nonrespondent ASOs in terms of number of employees $(p=0.310)$ and age $(p=0.139)$. Therefore, nonresponse bias poses no problem in our empirical data, and therefore, our sample can be assumed as representative of the total population of Spanish ASOs.

Step 5: Descriptive Analysis of the Total Sample

In order to ascertain the specific characteristics of our sample, a descriptive analysis was performed. In our sample, the average age of the firms was 6.5 years, although a significant diversity was reported in terms of age. In this respect, $28.8 \%$ of ASOs were between 1 and 3 years old; $26.6 \%$ were between 4 and 6 years old; $20.8 \%$ were between 7 and 9 years old; and $23.6 \%$ were over 10 years old. Furthermore, these firms employed an average of 17 people, and approximately $72 \%$ of the ASOs had non-academic managers in their teams at the moment of implementing the questionnaire. Moreover, the ASOs in our sample were located in different Spanish regions, whereby the most frequent locations were Andalusia $(25.4 \%)$, Catalonia (17\%), Galicia (11.6\%), and the Basque Country (11\%). Finally, $54.3 \%$ of the surveyed ASOs developed professional, scientific, and technical activities, including biotechnology, research and development, and chemistry; $15.6 \%$ of the ASOs operated in information and communication; and $12.7 \%$ of the ASOs in manufacturing.

Regarding the region in which ASOs are located, the COTEC report [89] states that the Basque Country and Catalonia have ecosystems that foster social innovation, in which there are financing mechanisms designed for this type of innovation, spaces for their development, and a participatory society in relation to social problems. This could lead to the existence of regional differences in our sample, which could affect the level of social innovation of ASOs. Therefore, in order to determine whether significant differences exist in the level of social innovation between the ASOs located in Catalonia or the Basque Country and those located in other regions, a t-test on independent samples was conducted. With this aim, a dummy variable was created that took value 1 if the ASO was located in Catalonia or the Basque Country, and 0 otherwise. The results of the $t$-test $(p=0.653)$ demonstrated that there were no significant differences regarding the level of social innovation between these two subsamples. Finally, in order to determine whether the industry in which ASOs operated affected their level of social innovation, a series of $t$-tests was developed that compared each of the industries in our sample with the total sample. Again, the results of these $t$-test analyses demonstrated that significant differences did not exist in the level of social innovation among ASOs operating in different industries ( $p=0.934$ for professional, scientific, and technical activities; $p=0.814$ for information and communication; $p=0.783$ for manufacturing; and $p=0.646$ for others). Hence, it is not necessary to 
test our hypotheses by differentiating the location or industry of the ASOs. Therefore, the total sample of ASOs can be used to perform the empirical analyses.

Step 6: Selection of the Variables

Taking into account that it is not necessary to classify ASOs by industry or location, these variables were disregarded in our study. Thus, since the overall objective of this research is to analyze the effects that the social and institutional contexts of the entrepreneurial ecosystem exert on the social innovation of ASOs, the following variables of the final version of the questionnaire were selected:

- Dependent variable: "Social innovation". In order to measure the social innovation of ASOs, our dependent variable was based on the Regional Social Innovation Index (RESINDEX), which provides a conceptual and empirical model that explores indicators of social innovation at organizational and regional levels [90]. This index is inspired by recent reports of the European Commission [91,92] and has been generated by SINNERGIAK Social Innovation [40]. Specifically, our focus was on the following three dimensions of the index: (i) acquisition of external knowledge; (ii) impact of social innovation; and (iii) social governance. First, in order to measure the acquisition of external knowledge for the development of social innovation, the main academic founder was requested to indicate, on a five-point Likert scale $(1=$ totally disagree; $5=$ totally agree), their level of agreement with the following statements: "We have employees or units focused on identifying social demands"; and "We use various sources of information to identify social demands" [42]. Second, we measured the impact of social innovation through the level of agreement of the main academic founder with the following statements, again on a five-point Likert scale ( $1=$ totally disagree; $5=$ totally agree): "Our innovations contribute to the development of products, processes, and/or services that resolve unsatisfied social demands, thereby improving people's way of life"; and "Our social innovations have a high degree of internationalization" [82]. Lastly, on the same Likert scale, social governance was reported through the level of agreement of the main academic founder with respect to both the degree of involvement of society in the identification of the social demands, and the degree of sustainability of the social innovation [42].

In order to ascertain whether these six items could be grouped to create a single social innovation variable, a principal component analysis was performed. The results of this analysis reported an appropriate level of internal consistency $(\alpha=0.86)$ and a correct sampling adequacy (Kaiser-Meyer-Olkin Test $=0.85$ ). The percentage of total variance explained rose to $58.3 \%$. In addition, as Hair et al. [93] recommended, all factor loadings were greater than 0.40 , and all communalities exceeded 0.50 .

- Independent variables: "Actors from the social and institutional contexts of the entrepreneurial ecosystem". In order to identify the key actors of the social and institutional contexts of the entrepreneurial ecosystem of ASOs, an extensive literature review was carried out, which revealed that the social context comprises relationships with national and international customers, suppliers, competitors, and VCs. The institutional context is composed of relationships with national and international government institutions, TTOs, incubators, other academics, chairs of entrepreneurs, and research centers [20,94,95]. By focusing on Mitchell [96] and Smith et al. [97], the frequency of contact was employed to measure the interactions of ASOs with each agent. The main academic founders were therefore asked to indicate on a five-point Likert scale (1: fewer than one contact per month; 5: multiple daily contact) the frequency of contact with: (i) national customers, suppliers, and competitors; (ii) international customers, suppliers, and competitors; (iii) national and international VCs; (iv) national and international government institutions; (v) national and international TTOs; and (vi) national and international university institutions.

- Control variables: "age" of the ASO and its "target market". On the one hand, the age of an ASO was measured by calculating the number of years from the founding of the firm until the year 2018. On the other hand, in order to measure the target market, we asked the main academic founder to indicate the option that best described the market in which the company operated: market niche 
(small and specific customer group); or dominant market (large market where several companies operate) [98].

Table A1 provides a detailed description of the measures used in the study.

\section{Step 7: Empirical Analyses}

Before contrasting our hypotheses, the descriptive statistics of the variables used in the study were calculated. Table 1 shows the means and standard deviations between dependent, independent, and control variables.

Table 1. Descriptive statistics.

\begin{tabular}{lcccc}
\hline \multicolumn{1}{c}{ Variables } & Min & Max & Mean & SD \\
\hline [1] Social innovation & 1.00 & 5.00 & 3.11 & 1.02 \\
[2] Frequency of contact with national customers, suppliers and competitors & 1.00 & 5.00 & 2.81 & 1.32 \\
[3] Frequency of contact with international customers, suppliers and competitors & 1.00 & 5.00 & 2.36 & 1.33 \\
[4] Frequency of contact with national and international VCs & 1.00 & 5.00 & 1.43 & 0.83 \\
[5] Frequency of contact with national and international government institutions & 1.00 & 5.00 & 1.70 & 0.83 \\
[6] Frequency of contact with national and international TTOs & 1.00 & 5.00 & 1.53 & 0.76 \\
[7] Frequency of contact with national and international university institutions & 1.00 & 5.00 & 2.00 & 1.00 \\
[8] Age & 1.00 & 15.00 & 6.47 & 3.89 \\
[9] Type of market & 1.00 & 2.00 & 1.12 & 0.33 \\
\hline
\end{tabular}

In addition, we analyzed the correlations between all variables of the model (see Table 2). As can be observed in Table 2, several correlations are higher than 0.5 . However, we developed a multicollinearity analysis in order to analyze the values of the variance inflation factor (VIF) and the condition indices. The results of this analysis indicated that both indices were within the established limits, that is, condition indices were lower than 10 , and VIFs were lower than 4 . Therefore, it can be concluded that multicollinearity among variables of the model poses no problem in our data.

Table 2. Correlation matrix.

\begin{tabular}{|c|c|c|c|c|c|c|c|c|c|}
\hline & [1] & [2] & [3] & [4] & [5] & [6] & [7] & [8] & [9] \\
\hline [1] & 1.00 & & & & & & & & \\
\hline [2] & 0.04 & 1.00 & & & & & & & \\
\hline [3] & 0.19 * & $0.55^{* *}$ & 1.00 & & & & & & \\
\hline [4] & 0.02 & $0.27^{* *}$ & $0.37^{* *}$ & 1.00 & & & & & \\
\hline [5] & $0.26^{* *}$ & $0.24^{* *}$ & $0.33^{* *}$ & $0.40^{* *}$ & 1.00 & & & & \\
\hline [6] & $0.26^{* *}$ & $0.21^{* *}$ & 0.10 & $0.27^{* *}$ & $0.53^{* *}$ & 1.00 & & & \\
\hline [7] & 0.16 & $0.27^{* *}$ & $0.34^{* *}$ & 0.30 ** & $0.47^{* *}$ & $0.51^{* *}$ & 1.00 & & \\
\hline [8] & 0.03 & -0.15 & 0.08 & -0.10 & 0.05 & -0.15 & -0.09 & 1.00 & \\
\hline [9] & 0.12 & $0.24^{* *}$ & $0.24^{* *}$ & 0.12 & -0.05 & -0.02 & 0.16 & -0.07 & 1.00 \\
\hline
\end{tabular}

Once the descriptive statistics of the variables used in our research were studied and it was verified that there was no multicollinearity in our data, the statistical technique was selected to test our hypotheses and answer our first research question ("What actors of the social and institutional contexts contribute to improve social innovation of ASOs?"). Considering that the dependent variable is measured on a continuous scale and that the independent variables are categorical and continuous, linear regressions between said variables can be applied to predict the social innovation variable. Therefore, it is assumed that the application of linear regressions is appropriate in our study.

Table 3 shows the results of linear regression analysis, including control variables and independent variables. This table shows that the $\mathrm{R}^{2}$ value for the model is $16.3 \%$, while adjusted $\mathrm{R}^{2}$ is $11.3 \%$. Furthermore, the overall model is highly significant $(\mathrm{F}=3.257, p<0.01)$. With respect to social context, our results show, on the one hand, that the frequency of contact with international customers, suppliers, and competitors is positively related to social innovation $(\beta=0.237 ; p<0.05)$. However, the frequency 
of contact with national customers, suppliers, and competitors is not significant $(\beta=-0.138 ; p=0.161$ ). Therefore, Hypothesis 1 is partially supported. On the other hand, the frequency of contact with international and national VCs is negatively related to the social innovation of ASOs $(\beta=-0.166$; $p<0.10$ ), which supports Hypothesis 2 . Regarding the institutional context, our results show that the frequency of contact with national and international government institutions $(\beta=0.191 ; p<0.10)$ and with national and international TTOs $(\beta=0.288 ; p<0.01)$ are positively and significantly related to social innovations of ASOs. However, no significant relationship can be found between the frequency of contact of other university institutions, such as university incubators, chairs of entrepreneurs, among others, and social innovation of ASOs ( $\beta=-0.100 ; p=0.333)$. Based on these results, Hypothesis 3 is partially supported.

Table 3. Results of the linear regression analysis.

\begin{tabular}{|c|c|c|c|c|c|}
\hline \multirow[t]{2}{*}{ Variables } & \multicolumn{2}{|c|}{$\begin{array}{l}\text { Non-Standardized } \\
\text { Coefficients }\end{array}$} & \multicolumn{3}{|c|}{ Standardized Coefficients } \\
\hline & $\beta$ & Std. Error & $\beta$ & t & $\alpha$ \\
\hline Constant & -1.042 & 0.411 & & -2.533 & $0.012 *$ \\
\hline Age & 0.005 & 0.022 & 0.019 & 0.229 & 0.819 \\
\hline Target market & 0.363 & 0.263 & 0.117 & 1.382 & 0.169 \\
\hline $\begin{array}{l}\text { Frequency of contact with national customers, suppliers and } \\
\text { competitors }\end{array}$ & -0.104 & 0.074 & -0.138 & -1.408 & 0.161 \\
\hline $\begin{array}{l}\text { Frequency of contact with international customers, suppliers } \\
\text { and competitors }\end{array}$ & 0.178 & 0.080 & 0.237 & 2.220 & $0.028 *$ \\
\hline Frequency of contact with national and international VCs & -0.202 & 0.113 & -0.166 & -1.790 & $0.076+$ \\
\hline $\begin{array}{l}\text { Frequency of contact with national and international } \\
\text { government institutions }\end{array}$ & 0.233 & 0.130 & 0.191 & 1.784 & $0.077+$ \\
\hline Frequency of contact with national and international TTOs & 0.383 & 0.141 & 0.288 & 2.729 & $0.007 * *$ \\
\hline $\begin{array}{l}\text { Frequency of contact with national and international } \\
\text { university institutions }\end{array}$ & -0.102 & 0.105 & -0.100 & -0.972 & 0.333 \\
\hline $\mathrm{F}$ & $3.26^{* *}$ & & & & \\
\hline$R^{2}$ & 0.163 & & & & \\
\hline Adjusted $R^{2}$ & 0.113 & & & & \\
\hline
\end{tabular}

+ Significant at $\alpha \leq 0.10 .{ }^{*}$ Significant at $\alpha \leq 0.05 .{ }^{* *}$ Significant at $\alpha \leq 0.01$.

In order to corroborate the results of the linear regression analysis explained above and answer our second research question ("Which of the social or institutional context is more relevant for social innovation of ASOs?"), the partial and semipartial coefficients of correlation of the dependent variable with respect to each type of actor were taken into account in order to determine the relative importance of the frequency of contact with each actor for the social innovation of ASOs [99,100]. As can be observed in Table 4, the partial and semipartial coefficients of correlation of the frequency of contact with national customers, suppliers, and competitors and the frequency of contact with other national and international university institutions are not significant (the 0 falls within the confidence intervals). It can therefore be assumed that frequent contact with these actors fails to contribute towards explaining the degree to which the ASOs develop social innovation. These results corroborate the conclusions drawn initially from the coefficients of regression obtained in our model (Table 3). In addition, the results of Table 4 confirm that frequent contact with international customers, suppliers, and competitors and with national VCs, government institutions, and TTOs remains significant. Moreover, the partial and semipartial coefficients of the frequency of contact with national and international TTOs are higher ( 0.229 and 0.216 , respectively) than those maintained with other agents. Hence, the results indicate that the frequency of contact with national and international TTOs carries greater importance for the social innovation of ASOs than does the frequency of contact with other actors from social and institutional contexts. Furthermore, the most relevant agents from the social context are international customers, suppliers, and competitors (partial correlations $=0.188$; semipartial coefficients $=0.175$ ). 
Table 4. Zero-order, partial, and semipartial correlation coefficients of the linear regression model.

\begin{tabular}{|c|c|c|c|c|c|c|c|}
\hline \multirow[t]{2}{*}{ Variables } & \multicolumn{2}{|c|}{$\begin{array}{l}95 \% \text { Confidence } \\
\text { Interval }\end{array}$} & \multicolumn{2}{|c|}{$\begin{array}{l}\text { 90\% Confidence } \\
\text { Interval }\end{array}$} & \multicolumn{3}{|c|}{ Correlations } \\
\hline & $\begin{array}{l}\text { Lower } \\
\text { Limit }\end{array}$ & $\begin{array}{l}\text { Upper } \\
\text { Limit }\end{array}$ & $\begin{array}{c}\text { Lower } \\
\text { Limit }\end{array}$ & $\begin{array}{l}\text { Upper } \\
\text { Limit }\end{array}$ & Zero-Order & Partial & Semi-Partial \\
\hline Age & -0.038 & 0.048 & -0.031 & 0.041 & 0.035 & 0.020 & 0.018 \\
\hline Target market & -0.157 & 0.882 & -0.072 & 0.798 & 0.089 & 0.119 & 0.109 \\
\hline $\begin{array}{l}\text { Frequency of contact with national } \\
\text { customers, suppliers and competitors }\end{array}$ & -0.251 & 0.042 & -0.227 & 0.018 & 0.046 & -0.121 & -0.111 \\
\hline $\begin{array}{l}\text { Frequency of contact with } \\
\text { international customers, suppliers } \\
\text { and competitors }\end{array}$ & 0.019 & 0.337 & 0.045 & 0.312 & 0.191 & 0.188 & 0.175 \\
\hline $\begin{array}{l}\text { Frequency of contact with national and } \\
\text { international VCs }\end{array}$ & -0.425 & 0.021 & -0.388 & -0.015 & 0.029 & -0.153 & -0.141 \\
\hline $\begin{array}{l}\text { Frequency of contact with national and } \\
\text { international government institutions }\end{array}$ & -0.025 & 0.491 & 0.017 & 0.449 & 0.272 & 0.152 & 0.0141 \\
\hline $\begin{array}{l}\text { Frequency of contact with national and } \\
\text { international TTOs }\end{array}$ & 0.106 & 0.661 & 0.151 & 0.616 & 0.277 & 0.229 & 0.0216 \\
\hline $\begin{array}{l}\text { Frequency of contact with national and } \\
\text { international university institutions }\end{array}$ & -0.309 & 0.105 & -0.275 & 0.072 & 0.140 & -0.084 & -0.077 \\
\hline
\end{tabular}

\section{Discussion}

Through knowledge transfer and entrepreneurial activities, universities play a major role in the promotion of social innovations that contribute towards the "grand societal challenges": a new class of contemporary problems that are not solvable exclusively via more economic growth [101]. Within this field of study, our work aims to answer two research questions: (i) What agents from the social and institutional contexts of the entrepreneurial ecosystem contribute to improve social innovation of ASOs?; and (ii) Which of these contexts, social or institutional, is more relevant? In general, our results indicate that both contexts are relevant for the development of social innovation, although the university institutional context is the most relevant in the form of TTOs. This last finding may be due to the idiosyncratic characteristics of the ASO firms analyzed.

Regarding the social context, results showed that frequent contact with international clients, suppliers, and competitors positively contributes towards the development of social innovation in ASOs, while the establishment of close relationships with VCs reduces the likelihood of these firms developing social innovations.

Several reasons explain the major role played by international clients, suppliers, and competitors. First, these agents constitute a direct source of knowledge related to existing and latent social problems $[12,13]$. The university context from which ASOs emanate is not always permeable to the real social problems and demands; therefore, maintaining contact with these agents from the market allows ASOs to access knowledge, regarding the social applications of their scientific discoveries, of a more accurate nature. Second, companies with a greater propensity towards social innovation are those that go beyond their own limits and establish relations with social agents and agents from the market [12,85], which implies identifying, exploring, and integrating their viewpoints [35]. As Windrum et al. [12] (p. 4) state, "social innovation is "social" both in its outcome and in its process. The agents involved in social innovation seek to address a societal challenge, based on new ways of empowering citizens and establishing new social relationships". Furthermore, identifying, exploring, and integrating the different viewpoints of clients, suppliers, and competitors enables the development of the co-creation process which is the key for the generation of social innovations in ASOs.

The results also show that it is the international clients, suppliers, and competitors that are most relevant for social innovation. This result is concordant with the international vocation of ASOs. Indeed, previous studies show that ASOs are created with a strong international orientation [102,103], due to the specific characteristics of the industries and markets where they compete; the accelerated pace of technological innovation worldwide; the high cost of research and development that must be amortized; and the nature of their products and services [103]. The relevance of international clients, suppliers, and competitors can also be explained by the fact that, in many cases, ASOs originate from 
results obtained in international research projects. In this respect, among the different programs within Horizon 2020, emphasis should be laid on the "Science with and for society" program. This program is based on financing international research projects that seek to develop innovations in collaboration with agents from a social context in order to align the results of these innovations with the values, needs, and expectations of European society.

With respect to the effect of VC firms, our results confirm our second hypothesis. Thus, results indicate that since ASOs increase contact with VCs, an exoisomorphism with the financial objectives of these companies emerges and negatively influences the development of social innovations in ASOs. In this regard, Souitaris et al. [74] considered that companies tend to align their initial objectives with the objectives of the VCs when the proximity to these agents increases. In this way, the shared experiences with VCs would lead ASOs to interiorize the objective of creating products and services to obtain high economic performance in the markets and to move away from their initial motivations of creating and commercializing scientific knowledge to solve the great problems of society. The arguments by Benneworth and Cunha [101] support that universities are actors with clear public duties, which engage with and stimulate (co-operative) social innovation processes but also show very strong private interests related to their institutional performance, survival, and evolution. Consequently, ASOs may inherit this conflict of interests from their parent universities and choose to assume a more commercial and competitive orientation in an effort to attain funding from VCs. In this case, ASOs emphasize profit outcomes. Hellmman and Puri [104] demonstrated that start-ups that are backed by VC firms introduce more radical innovations in their markets and pursue business strategies of a more aggressive nature. In sum, VCs are not usually an agent that financially supports ASOs' social innovations by prioritizing only financial returns. Given these circumstances, another relatively new type of financial agent interested in financing social entrepreneurial projects has emerged. These agents are called impact investors and expect to receive two types of returns: a financial return on investment and a social return on investment $[8,14,105,106]$. In the case of ASOs, impact investors could constitute an adequate financial instrument [8]. This is because the innovations of the ASOs could create sustainable value for society, and also, the technologies or knowledge on which these innovations are based are usually cutting-edge and have a high growth potential. Therefore, a dual value-financial and social—could be derived from ASOs' innovations.

With regard to the institutional context, results have shown that frequent contact with and support from government institutions and TTOs favors the development of social innovation in ASOs. In this vein, governments develop a more favorable context to create social innovation through the application of specific regulatory mechanisms such as laws, decrees and directives, and tax incentives [76,107,108]. Moreover, the closeness with these agents can lead ASOs to attain knowledge of and access to funding for the development of research projects focused on social and sustainable innovation. In this respect, at the European level, government institutions offer funding through the Horizon 2020 program, which reflects the current policy priorities related to social challenges of the European Union. In this vein, the conclusions of the CYD Foundation (Knowledge and Development Foundation) Report 2018 [109] point out that the European Union should support universities and public research institutes to participate in a socially inclusive and sustainable research, development, and innovation recruitment as a fundamental part of funding instruments such as Erasmus+, Horizon 2020 and European structural funds and investment. At a national level, Spanish government institutions, such as the Ministry of Science, Innovation, and Universities, are committed to financing research projects within universities that strive to develop innovations that promote economic and social change and progress. Through these European and national funds, ASOs may develop research projects, whose results become the seed for the continuous development of social innovation. These policies seem to be increasingly valuable for society. To this respect, the III Innovation Social Perception Survey, which was carried out by the COTEC Foundation in January 2020 [110] from a sample of 2404 Spanish adults, reveals that $27.2 \%$ of respondents primarily perceive innovation as a process of social transformation. 
Regarding the relevant role performed by TTOs in the development of social innovations, recent studies have highlighted that a growing number of universities are integrating the notions of sustainability, corporate social responsibility, and social innovation into their goals, visions, mission, and priority areas. Furthermore, the objectives of social innovation and sustainability are being incorporated into the university support system for entrepreneurship [111]. In this way, TTOs can transmit this culture and these goals to the academic entrepreneurs, which increases the likelihood of recognizing socially sustainable business opportunities. Fichter and Tiemman [7] and Paniccia and Biaocco [6] found that TTOs constitute appropriate mechanisms for the transmission and materialization of a culture oriented towards the commercialization of social innovation. On the other hand, several authors state that TTOs develop additional support functions for ASOs that may contribute towards the development of innovations, in general, and social innovations in particular $[7,86]$. First, prior research has shown that TTOs are sources of supportive activities such as consultancy services, management training, administrative and legal tasks, and human resource services that facilitate the development of ASOs [95,112-114]. Second, TTOs are considered as providers of business competences and credibility, which are necessary to operate in markets [113,115-117]. Finally, a crucial function of TTOs, which positively influences the development of social innovation by ASOs, involves the provision of access to networks with social agents $[7,86]$. Thus, Breznitz et al. [86] consider that one of the most relevant resources with which TTOs can provide ASOs is that of a network of relationships with agents from the social context. Specifically, Tekula and Jahmb [8] proposed that academic agents can act as intermediaries between ASOs and impact investors. In this way, these firms can rely on these hybrid investors in order to access financing, which they can hardly access through VCs [8].

Results regarding our second research question revealed that the institutional context, mainly consisting of TTOs, is more influential in the development of social innovation by ASOs than is the social context. This result confirms that TTOs provide ASOs with the most relevant resources and capacities for social innovation. As we stated above, TTOs influence the culture and vision that ASOs must adopt to develop social innovation. In addition, TTOs collaborate with ASOs to define the opportunities identified from their research in the social setting. Finally, TTOs serve as initial support for the commercialization of these innovations, through consultancy services, management training, etc., and act as a bridge to establish contact with agents from the social context.

The relevance of TTOs in the development of social innovation in ASOs differs from that of other organizations that fall outside the university context and therefore justifies the need to analyze the influence of the entrepreneurial ecosystem on the development of social innovation by ASOs. In addition, the study by Franco-Leal et al. [20] indicated that TTOs are irrelevant for the economic performance of ASOs. This means that according to the ecosystem theory, the contexts of the entrepreneurial ecosystem affect the results of the companies in different ways, and hence, depending on the type of result or innovation developed by the firm, companies need to rely on different contexts of the entrepreneurial ecosystem [21]. Both factors justify the relevance and need for the development of a specific analysis regarding how the contexts of the entrepreneurial ecosystem affect social innovation of ASOs.

Finally, an overall vision of the results shows that the development of social innovations by ASOs depends on how the university, industry, and government synergistically interact $[6,118]$. Among these innovation actors, the university plays a critical role by generating and transferring the most important raw material, that of scientific knowledge, for economic and social growth through innovative entrepreneurial activities [6,119].

\section{Conclusions}

This study has confirmed the importance of the social and institutional (governmental and university) contexts of the entrepreneurial ecosystem of ASOs for the development of social innovations. These results, in addition to the premises of the entrepreneurial ecosystem theory, confirm the Sustainability Twin-Helix Model $[6,120]$. This model identifies three spheres (university, government, 
and agents from the social context) that can interact and exert a specific influence on social innovation. In this respect, this model establishes that agents from the social context act by sharing knowledge about demands and problems of society; governments establish mechanisms for coordination, regulation, and financing in order to resolve these social demands; and universities act as agents that promote the creation of knowledge bases for the development of social innovation and its subsequent commercialization through ASOs to solve the great challenges of society [6].

The study provides major theoretical and empirical contributions for research within the field of academic entrepreneurship. On the one hand, within the academic entrepreneurship field, research is fragmented, in that it fails to consider the full array of factors that shape academic entrepreneurship. In this vein, Hayter at al. [64], in their review of the extant literature, stated that current research provides specific insights but does not reflect an ecosystem perspective on the phenomenon, except for the study by Clarysse et al. [121]. For that reason, these authors considered that advancing research in this field implies addressing the study of academic entrepreneurship from an ecosystem perspective [64]. Therefore, our research covers a major gap in the literature. On the other hand, despite the fact that the entrepreneurial university as a research field and the research field of the sustainable university are both growing, hitherto, there has been no interconnection between these fields. There is a clear gap in university entrepreneurship research with regard to social innovation and vice versa, and only very limited research carried out on support systems for sustainable entrepreneurship [7]. Finally, in order to advance research in the field of academic entrepreneurship and its influence on social innovation, the application of a network perspective is required, which involves the consideration of the structure that connects a multitude of actors that cooperate and co-evolve. The network perspective is at the heart of the ecosystem perspective [7] and the Sustainability Twin-Helix Model [118].

A series of practical implications for governments, universities, and academic entrepreneurs can be derived from this research. With respect to governments, their efforts should be focused on establishing mechanisms to finance research projects developed in universities and related to solving the great challenges of society, which can subsequently be commercialized through the creation of ASOs. Not only should this funding be aimed at stimulating the creation of scientific knowledge bases to solve social demands, but it should also establish ASOs focused on social innovations. Furthermore, governments should continue to develop fiscal and normative programs to create a specific regulatory environment for these companies in order to stimulate their creation and future development. As Mazzucato [122] suggests, the state should reinforce its role as creator of social innovations and markets, and specifically, policies not should be focused "on technological challenges alone, but rather on areas traditionally falling under public services such as education or welfare state, and entail changes across various economic and policy sectors" [123] (p. 6). Focusing on Spain, the information provided by the COTEC Report 2017 [124] reveals that Spain does not have an explicit and well-articulated social innovation policy at the state level, since it is ranked 26th out of 45 countries analyzed by the Social Innovation Index. This report notes a series of structural problems that should be solved in order to develop an institutional framework that contributes to build a supportive innovative ecosystem. Thus, the lack of clarity of the specific regulatory framework, the scarcity of a demand of explicit social innovations by the public administrations or the absence of a global policy led by the National Government that integrates the efforts of local, regional, and national public administrations, market agents, and higher-education institutions should be specifically addressed in order to improve the performance of Spain in terms of social innovation. These aforementioned barriers of the national institutional framework could explain why social innovation in ASOs is primarily supported by TTOs instead of by government institutions. Regarding universities, these institutional agents should be aware of the need to bring ASOs closer to the agents of the social context. In particular, through TTOs, universities should form a bridge between these companies and networks of relationships with potential customers, suppliers, and competitors in order to provide direct access to information on social problems and to ways to solve these in a sustainable manner. In this vein, the Social Council Conference of the Spanish Universities, through the report conducted by Rubio 
de las Alas-Pumariño [125], notes, among a set of recommendations, that universities should benefit from the open innovation strategy offered by many companies, which are willing to participate with third parties to develop joint projects and which can be offered solutions to certain problems. This recommendation is aligned with the arguments of Mazzucato [126], who noted that inclusive and sustainable innovation policy requires a new framework based on market co-creating. Specifically, policies should "be broad enough to engage the public, enable concrete missions, attract cross-sectorial investment, and remain focused enough to involve industry and achieve measurable success" [123]. Moreover, universities should continue to internalize the cultural values related to corporate social responsibility in order to enable their transmission to research groups during the development of their research for the creation and commercialization of scientific knowledge that can meet social demands. Finally, academic entrepreneurs should be aware of the importance of maintaining frequent contact with institutional agents and agents from the social context in order to access key resources and capacities to initiate and successfully develop processes of social innovation.

Our study presents a series of limitations from which future lines of research may be derived. The first limitation is related to the employment of cross-sectional data, which precludes drawing inferences regarding the causal direction of the relationships established. We established these causal relationships based on the result of the premises of entrepreneurial ecosystem theory and network literature within the academic entrepreneurship literature [21,97]. Nevertheless, taking into account that our data are cross-sectional, it cannot be ascertained whether the relationships of causality developed in our research may operate in the opposite direction. Second, since our study is one of the first attempts to link the effects of the structure of the network with the theory of entrepreneurial ecosystems, only the frequency of contact has been analyzed. Therefore, future research could also analyze the size of the network and/or the structural gaps in entrepreneurial ecosystems in order to ascertain their effects on social innovation of these entrepreneurial initiatives. Third, the fact that our sample is composed of solely Spanish ASOs may cause problems in the representativeness of the results, which in turn may constrain their generalization to other countries [127]. Future research should include ASOs from different nations in order to obtain more generalizable results. Finally, our study centers on the influence of the institutional and social contexts of the entrepreneurial ecosystem on only one of the dimensions of innovation of ASOs: the social dimensions. It would be interesting carry out an analysis to compare the influence of the entrepreneurial ecosystem on different types of ASO innovations, or on both the social and business dimensions of innovations.

Author Contributions: The authors contributed equally to curating and analyzing the data and writing the paper. All authors have read and agreed to the published version of the manuscript.

Funding: This work was supported by the Spanish Ministry of Economy and Competitiveness and European Regional Development Fund, Grant Number: ECO2015-67721-P.

Conflicts of Interest: The authors declare there to be no conflict of interest. 


\section{Appendix A}

Table A1. Measurement of the variables.

\begin{tabular}{l} 
Social Innovation (SINNERGIAK Social Innovation, 2013) \\
\hline Please, indicate on a five-point Likert scale (1 = totally disagree; $5=$ totally agree), your level of agreement with the \\
following statements: \\
We have employees or units focused on identifying social demands \\
We use various sources of information to identify social demands \\
Our innovations contribute to the development of products, processes, and/or services that resolve unsatisfied \\
social demands, thereby improving people's way of life \\
Our social innovations have a high degree of internationalization \\
The degree of involvement of the society in the identification of the social demands is high \\
The degree of sustainability of the social innovation is high \\
Social context (Mitchell, 1982; Smith et al., 2005; Mosey and Wright, 2007; Franco-Leal et al., 2019) \\
\hline Please, indicate on a five-point Likert scale (1 = fewer than one contact per month; $5=$ multiple daily contact) the \\
frequency of contact with the following actors: \\
National customers, suppliers, and competitors \\
International customers, suppliers, and competitors \\
National and international VC firms \\
\hline Institutional context (Mitchell, 1982; Smith et al., 2005; Mosey and Wright, 2007; Franco-Leal et al., 2019) \\
\hline Please, indicate on a five-point Likert scale (1 = fewer than one contact per month; $5=$ multiple daily contact) the \\
frequency of contact with the following actors: \\
National and international government institutions \\
National and international TTOs \\
National and international university institutions \\
\hline Please, indicate the year in which the ASO was founded: \\
\hline Target market (Clarysse et al., 2007) \\
\hline Please, indicate the option that best describes the market of the company: \\
Market niche (small and specific customer group) \\
Dominant market (large market where several companies operate) \\
\hline
\end{tabular}

\section{References}

1. Mustar, P.; Renault, M.; Colombo, M.G.; Piva, E.; Fontes, M.; Lockett, A.; Wright, M.; Clarysse, B.; Moray, N. Conceptualising the heterogeneity of research-based spin-offs: A multi-dimensional taxonomy. Res. Policy 2006, 35, 289-308. [CrossRef]

2. Mustar, P.; Wright, M.; Clarysse, B. University spin-off firms: Lessons from ten years of experience in Europe. Sci. Public Policy 2008, 35, 67-80. [CrossRef]

3. Scholten, V.; Van Der Duin, P. Responsible innovation among academic spin-offs: How responsible practices help developing absorptive capacity. J. Chain Netw. Sci. 2015, 15, 165-179. [CrossRef]

4. Fini, R.; Rasmussen, E.; Siegel, D.; Wiklund, J. Rethinking the Commercialization of Public Science: From Entrepreneurial Outcomes to Societal Impacts. Acad. Manag. Perspect. 2018, 32, 4-20. [CrossRef]

5. Lundström, A.; Zhou, C. Promoting innovation based on social sciences and technologies: The prospect of a social innovation park. Innov. Eur. J. Soc. Sci. Res. 2011, 24, 133-149. [CrossRef]

6. Paniccia, P.M.A.; Baiocco, S. Co-Evolution of the University Technology Transfer: Towards a Sustainability-Oriented Industry: Evidence from Italy. Sustainability 2018, 10, 4675. [CrossRef]

7. Fichter, K.; Tiemann, I. Factors influencing university support for sustainable entrepreneurship: Insights from explorative case studies. J. Clean. Prod. 2018, 175, 512-524. [CrossRef]

8. Tekula, R.; Shah, A.; Jhamb, J. Universities as Intermediaries: Impact Investing and Social Entrepreneurship. Acad. Manag. Proc. 2015, 2015, 18886. [CrossRef] 
9. Nejabat, R.; Taheri, M.; Scholten, V.; Van Geenhuizen, M. University spin-offs' steps in commercialization of sustainable energy inventions in northwest Europe. In Cities and Sustainable Technology Transitions: Leadership, Innovation and Adoption; Van Geenhuizen, M., Hobrook, A., Taheri, M., Eds.; Edward Elgar Publishing: Cheltenham, UK, 2018; pp. 59-87.

10. Hazenberg, R.; Bajwa-Patel, M.; Roy, M.J.; Mazzei, M.; Baglioni, S. A comparative overview of social enterprise 'ecosystems' in Scotland and England: An evolutionary perspective. Int. Rev. Sociol. 2016, 26, 205-222. [CrossRef]

11. Kabbaj, M.; Hadi, K.E.O.E.; Elamrani, J.; Lemtaoui, M. A Study of the Social Entrepreneurship Ecosystem: The Case Of Morocco. J. Dev. Entrep. 2016, 21, 1650021. [CrossRef]

12. Windrum, P.; Schartinger, D.; Rubalcaba, L.; Gallouj, F.; Toivonen, M. The co-creation of multi-agent social innovations: A bridge between service and social innovation research. Eur. J. Innov. Manag. 2016, 19, 150-166. [CrossRef]

13. Melane-Lavado, A.; Álvarez-Herranz, A. Different Ways to Access Knowledge for Sustainability-Oriented Innovation. The Effect of Foreign Direct Investment. Sustainability 2018, 10, 4206. [CrossRef]

14. Roundy, P.T. Social Entrepreneurship and Entrepreneurial Ecosystems: Complementary or Disjointed Phenomena? SSRN Electron. J. 2017, 44, 1252-1267. [CrossRef]

15. Hota, P.K.; Villari, B.C.; Subramanian, B. Developing Platform Ecosystem for Resource Mobilization: The Case of Social Enterprises in India. J. Inf. Technol. Case Appl. Res. 2018, 20, 71-85. [CrossRef]

16. Thomsen, B.; Muurlink, O.; Best, T. The political ecology of university-based social entrepreneurship ecosystems. J. Enterp. Commun. People Places Glob. Econ. 2018, 12, 199-219. [CrossRef]

17. Autio, E.; Nambisan, S.; Thomas, L.D.W.; Wright, M. Digital affordances, spatial affordances, and the genesis of entrepreneurial ecosystems. Strat. Entrep. J. 2018, 12, 72-95. [CrossRef]

18. De Bruin, A.; Shaw, E.; Lewis, K.V. The collaborative dynamic in social entrepreneurship. Entrep. Reg. Dev. 2017, 29, 575-585. [CrossRef]

19. Alvedalen, J.; Boschma, R. A critical review of entrepreneurial ecosystems research: Towards a future research agenda. Eur. Plan. Stud. 2017, 88, 1-17. [CrossRef]

20. Franco-Leal, N.; Camelo-Ordaz, C.; Fernandez-Alles, M.; Sousa-Ginel, E. The Entrepreneurial Ecosystem: Actors and Performance in Different Stages of Evolution of Academic Spinoffs. Entrep. Res. J. 2019, in press. [CrossRef]

21. Autio, E.; Kenney, M.; Mustar, P.; Siegel, D.; Wright, M.; Wright, D. Entrepreneurial innovation: The importance of context. Res. Policy 2014, 43, 1097-1108. [CrossRef]

22. Nicotra, M.; Romano, M.; Del Giudice, M.; Schillaci, C.E. The causal relation between entrepreneurial ecosystem and productive entrepreneurship: A measurement framework. J. Technol. Transfer 2018, 43, 640-673. [CrossRef]

23. Van De Ven, H. The development of an infrastructure for entrepreneurship. J. Bus. Ventur. 1993, 8, 211-230. [CrossRef]

24. Bhatt, P.; Altinay, L. How social capital is leveraged in social innovations under resource constraints? Manag. Decis. 2013, 51, 1772-1792. [CrossRef]

25. Spilling, O.R. The entrepreneurial system: On entrepreneurship in the context of a mega-event. J. Bus. Res. 1996, 36, 91-103. [CrossRef]

26. Stam, E. Entrepreneurial Ecosystems and Regional Policy: A Sympathetic Critique. Eur. Plan. Stud. 2015, 23, 1759-1769. [CrossRef]

27. Spigel, B.; Harrison, R. Toward a process theory of entrepreneurial ecosystems. Strateg. Entrep. J. 2018, 12, 151-168. [CrossRef]

28. Nicholls, A. Playing the field: A new approach to the meaning of social entrepreneurship. Soc. Enter. J. 2006, $2,1-5$.

29. Nicholls, A.; Murdock, A. The nature of social innovation. In Social Innovation; Palgrave Macmillan: London, UK, 2012; pp. 1-30.

30. Feld, B. Startup Communities: Building an Entrepreneurial Ecosystem in Your City; John Wiley \& Sons: Hoboken, NJ, USA, 2012.

31. Short, J.C.; Moss, T.W.; Lumpkin, G.T. Research in social entrepreneurship: Past contributions and future opportunities. Strat. Entrep. J. 2009, 3, 161-194. [CrossRef] 
32. Martinez, F.; O'Sullivan, P.; Smith, M.; Esposito, M. Perspectives on the role of business in social innovation. J. Manag. Dev. 2017, 36, 681-695. [CrossRef]

33. Gatignon, H.; Gotteland, D.; Haon, C.; Zimmer, J. Making Innovation Last: Sustainable Strategies for Long Term Growth; Palgrave Macmillan: London, UK, 2016.

34. Mulgan, G. The process of social innovation. Innov. Technol. Gov. Glob. 2006, 1, 145-162. [CrossRef]

35. Phills, J.; Deiglmeier, K.; Miller, D. Rediscovering Social Innovation. Stanford Social Innovation Review. Available online: https://search-proquest-com.bibezproxy.uca.es/docview/217166206?pq-origsite=summon (accessed on 22 January 2020).

36. Roome, N. Innovation, global change and new capitalism: A fuzzy context for business and the environment. Hum. Ecol. Forum 2004, 11, 277-280.

37. McKelvey, M.; Zaring, O. Co-delivery of social innovations: Exploring the university's role in academic engagement with society. Ind. Innov. 2018, 25, 594-611. [CrossRef]

38. Groot, A.; Dankbaar, B. Does social innovation require social entrepreneurship? Tech. Innov. Manag. Rev. 2014, 4, 17-26. [CrossRef]

39. European Commission. Empowering People, Driving Change: Social Innovation in the European Union [Electronic Version] 2011. Available online: http://www.ess-europe.eu/sites/default/files/publications/files/ social_innovation_0.pdf (accessed on 22 January 2020).

40. Dro, I.; Therace, A.; Hubert, A. Empowering People, Driving Change: Social Innovation in the European Union; European Commission: Brussels, Belgium, 2011. [CrossRef]

41. Adams, R.; Jeanrenaud, S.; Bessant, J.; Overy, P.; Denyer, D. Innovating for Sustainability: A Systematic Review of the Body of Knowledge. 2012. Available online: http://nbs.net/wp-content/uploads/NBS-SystematicReview-Innovation.pdf (accessed on 22 January 2020).

42. Sinnergiak Social Innovation. Regional Social Innovation Index. In A Regional Index to Measure Social Innovation; Basque Innovation Agency: Bilbao, Spain, 2013.

43. Pol, E.; Ville, S. Social innovation: Buzz word or enduring term? J. Socio-Econ. 2009, 38, 878-885. [CrossRef]

44. Crane, A.; Palazzo, G.; Spence, L.J.; Matten, D. Contesting the Value of "Creating Shared Value". Calif. Mana. Rev. 2014, 56, 130-153. [CrossRef]

45. Murray, R.; Mulgan, G.; Caulier-Grice, J. How to Innovate: The tools for social innovation. Retriev. April 2008, 28, 2012.

46. Tiemann, I.; Fichter, K.; Geier, J. University support systems for sustainable entrepreneurship: Insights from explorative case studies. Int. J. Entrepren. Ven. 2018, 10, 83-110. [CrossRef]

47. Hayter, C. In search of the profit-maximizing actor: Motivations and definitions of success from nascent academic entrepreneurs. J. Technol. Transfer 2011, 36, 340-352. [CrossRef]

48. Li, J.F.; Garnsey, E. Policy-driven ecosystems for new vaccine development. Technovation 2014, 34, 762-772. [CrossRef]

49. Maiolini, R.; Marra, A.; Baldassarri, C.; Carlei, V. Digital Technologies for Social Innovation: An Empirical Recognition on the New Enablers. J. Technol. Manag. Innov. 2016, 11, 22-28. [CrossRef]

50. Chin, T.; Yang, Y.; Zhang, P.; Yu, X.; Cao, L. Co-creation of social innovation: Corporate universities as innovative strategies for Chinese firms to engage with society. Sustainability 2019, 11, 1438. [CrossRef]

51. Bornmann, L. What is societal impact of research and how can it be assessed? A literature survey. J. Am. Soc. Inf. Sci. Tec. 2013, 64, 217-233. [CrossRef]

52. Zafeiropoulou, F.A.; Koufopoulos, D.N. The Influence of Relational Embeddedness on the Formation and Performance of Social Franchising. J. Mark. Channels 2013, 20, 73-98. [CrossRef]

53. Haugh, H. Community-Led Social Venture Creation. Entrep. Theory Pr. 2007, 31, 161-182. [CrossRef]

54. Dobele, L.; Pietere, A. Competitiveness of social entrepreneurship in latvia. Reg. Form. Dev. Stud. 2015, 17, 40-50. [CrossRef]

55. Dubini, P. The influence of motivations and environment on business start-ups: Some hints for public policies. J. Bus. Ventur. 1989, 4, 11-26. [CrossRef]

56. Grant, R.M. Toward a knowledge-based theory of the firm. Strat. Manag. J. 1996, 17, 109-122. [CrossRef]

57. Hansen, M.T. The Search-Transfer Problem: The Role of Weak Ties in Sharing Knowledge across Organization Subunits. Adm. Sci. Q. 1999, 44, 82. [CrossRef]

58. Reagans, R.; McEvily, B. Network Structure and Knowledge Transfer: The Effects of Cohesion and Range. Adm. Sci. Q. 2003, 48, 240. [CrossRef] 
59. Laursen, K.; Salter, A. Open for innovation: The role of openness in explaining innovation performance among U.K. manufacturing firms. Strateg. Manage. J. 2006, 27, 131-150. [CrossRef]

60. Semrau, T.; Werner, A. How exactly do network relationships pay off? The effects of network size and relationship quality on access to start-up resources. Entrep. Theory Pract. 2014, 38, 501-525. [CrossRef]

61. Rasmussen, E. The Regional Impacts of University Spin-offs: In What Ways do Spin-Offs Contribute to the Region? Forthcoming, Handbook on Universities and Regional Development; Edward Elgar Publishing: Cheltenham, UK, 2018; pp. 1-17.

62. Schillo, R.S. Research-based spin-offs as agents in the entrepreneurial ecosystem. J. Technol. Transfer 2018, 43, 222-239. [CrossRef]

63. Hayter, C.S. A trajectory of early-stage spinoff success: The role of knowledge intermediaries within an entrepreneurial university ecosystem. Small Bus. Econ. 2016, 47, 633-656. [CrossRef]

64. Hayter, C.S.; Nelson, A.J.; Zayed, S.; O'Connor, A.C. Conceptualizing academic entrepreneurship ecosystems: A review, analysis and extension of the literature. J. Technol. Transfer 2018, 43, 1039-1082. [CrossRef]

65. Shepherd, D.A.; Patzelt, H. The New Field of Sustainable Entrepreneurship: Studying Entrepreneurial Action Linking "What Is to Be Sustained" With “What Is to Be Developed". Entrep. Theory Pr. 2011, 35, 137-163. [CrossRef]

66. López-Martínez, R.E.; Medellín, E.; Scanlon, A.P.; Solleiro, J.L. Motivations and obstacles to university industry cooperation (UIC): A Mexican case. RED Manag. 1994, 24, 017-030.

67. Lyles, M.A.; Salk, J.E. Knowledge Acquisition from Foreign Parents in International Joint Ventures: An Empirical Examination in the Hungarian Context. J. Int. Bus. Stud. 1996, 27, 877-903. [CrossRef]

68. Karnani, F. The university's unknown knowledge: Tacit knowledge, technology transfer and university spin-offs findings from an empirical study based on the theory of knowledge? J. Technol. Transfer 2013, 38, 235-250. [CrossRef]

69. Gras, D.; Lumpkin, G.T. Strategic foci in social and commercial entrepreneurship: A comparative analysis. J. Soc. Entrep. 2012, 3, 6-23.

70. Lumpkin, G.T.; Moss, T.W.; Gras, D.M.; Kato, S.; Amezcua, A.S. Entrepreneurial processes in social contexts: How are they different, if at all? Small Bus. Econ. 2013, 40, 761-783. [CrossRef]

71. Lockett, A.; Murray, G.; Wright, M. Do UK venture capitalists still have a bias against investment in new technology firms? Res. Policy 2002, 31, 1009-1030. [CrossRef]

72. Vohora, A.; Wright, M.; Lockett, A. Critical junctures in the development of university high-tech spinout companies. Res. Policy 2004, 33, 147-175. [CrossRef]

73. Munari, F.; Toschi, L. Do venture capitalists have a bias against investment in academic spin-offs? Evidence from the micro- and nanotechnology sector in the UK. Ind. Corp. Chang. 2011, 20, 397-432. [CrossRef]

74. Souitaris, V.; Zerbinati, S.; Liu, G. Which Iron Cage? Endo-and exoisomorphism in Corporate Venture Capital Programs. Acad. Manag. J. 2012, 55, 477-505. [CrossRef]

75. Onyx, J.; Leonard, R. The Conversion of Social Capital into Community Development: An intervention in Australia's outback. Int. J. Urban Reg. Res. 2010, 34, 381-397. [CrossRef] [PubMed]

76. Bozhikin, I.; Macke, J.; Da Costa, L.F. The role of government and key non-state actors in social entrepreneurship: A systematic literature review. J. Clean. Prod. 2019, 226, 730-747. [CrossRef]

77. Pearson, C.A.L.; Helms, K. Indigenous Social Entrepreneurship: The Gumatj Clan Enterprise in East Arnhem Land. J. Entrep. 2013, 22, 43-70. [CrossRef]

78. Knott, J.H.; McCarthy, D. Policy venture capital foundations, government partnerships, and child care programs. Adm. Soc. 2007, 39, 319-353. [CrossRef]

79. Griffiths, M.D.; Gundry, L.K.; Kickul, J.R. The socio-political, economic, and cultural determinants of social entrepreneurship activity an empirical examination. J. Small Bus. Enterp. Dev. 2013, 20, 341-357. [CrossRef]

80. Thompson, J.L. The world of the social entrepreneur. Int. J. Public Sect. Manag. 2002, 15, 412-431. [CrossRef]

81. Westlund, H.; Gawell, M. Building Social Capital for Social Entrepreneurship. Ann. Public Cooperative Econ. 2012, 83, 101-116. [CrossRef]

82. Teasdale, S.; Lyon, F.; Baldock, R. Playing with Numbers: A Methodological Critique of the Social Enterprise Growth Myth. J. Soc. Entrep. 2013, 4, 113-131. [CrossRef]

83. Lozano, R.; Ceulemans, K.; Alonso-Almeida, M.; Huisingh, D.; Lozano, F.J.; Waas, T.; Lambrechts, W.; Lukman, R.; Hugé, J. A review of commitment and implementation of sustainable development in higher education: Results from a worldwide survey. J. Clean. Prod. 2015, 108, 1-18. [CrossRef] 
84. Fichter, K.; Clausen, J. Diffusion Dynamics of Sustainable Innovation-Insights on Diffusion Patterns Based on the Analysis of 100 Sustainable Product and Service Innovations. J. Innov. Manag. 2016, 4, 30-67. [CrossRef]

85. Disterheft, A.; Caeiro, S.; Azeiteiro, U.M.; Filho, W.L. Sustainable universities e a study of critical success factors for participatory approaches. J. Clean. Prod. 2015, 106, 11-21. [CrossRef]

86. Breznitz, S.M.; Clayton, P.A.; Defazio, D.; Isett, K.R. Have you been served? The impact of university entrepreneurial support on start-ups' network formation. J. Technol. Transfer 2018, 43, 343-367. [CrossRef]

87. Ensley, M.D.; Hmieleski, K.M. A comparative study of new venture top management team composition, dynamics and performance between university-based and independent start-ups. Res. Policy 2005, 34, 1091-1105. [CrossRef]

88. Scholten, V.E. The Early Growth of Academic Spin-Offs: Factors Influencing the Early Growth of Dutch Spin-Offs in the Life Sciences, ICT and Consulting. Ph.D. Thesis, Wageningen University, Wageningen, The Netherlands, 2006.

89. COTEC Report. Fundación COTEC para la Innovación. 2018. Available online: http://informecotec.es/media/ Informe-Cotec_2018_versi\%C3\%B3nweb.pdf (accessed on 22 January 2020).

90. Unceta, A.; Castro-Spila, J.; Fronti, J.G. Social innovation indicators. Innov. Eur. J. Soc. Sci. Res. 2016, 29 , 1-13. [CrossRef]

91. European Commission. Strengthening social innovation in Europe. Journey to Effective Assessment and Metrics [Electronic Version] 2012. Available online: http://ec.europa.eu/enterprise/policies/innovation/files/ social-innovation/strengthening-social-innovation_en.pdf (accessed on 22 January 2020).

92. European Commission. Guide to social innovation. Regional and urban policy/employment, social affairs and inclusion. [Electronic Version]. 2013. Available online: http://ec.europa.eu/regional_policy/sources/ docgener/presenta/social_innovation/social_innovation_2013.pdf (accessed on 22 January 2020).

93. Hair, J.F.; Black, W.C.; Babin, B.J.; Anderson, R.E.; Tatham, R.L. Multivariate Data Analysis; Pearson Prentice Hall: Upper Saddle River, NJ, USA, 2006.

94. Mosey, S.; Wright, M. From Human Capital to Social Capital: A Longitudinal Study of Technology-Based Academic Entrepreneurs. Entrep. Theory Pr. 2007, 31, 909-935. [CrossRef]

95. Fernández-Alles, M.; Camelo-Ordaz, C.; Franco-Leal, N. Key resources and actors for the evolution of academic spin-offs. J. Technol. Transfer 2015, 40, 976-1002. [CrossRef]

96. Mitchell, R.E. Social networks and psychiatric clients: The personal and environmental context. Am. J. Commun. Psychol. 1982, 10, 387-401. [CrossRef] [PubMed]

97. Smith, K.G.; Collins, C.J.; Clark, K.D. Existing Knowledge, Knowledge Creation Capability, and the Rate of New Product Introduction in High-Technology Firms. Acad. Manag. J. 2005, 48, 346-357. [CrossRef]

98. Clarysse, B.; Wright, M.; Lockett, A.; Mustar, P.; Knockaert, M. Academic spin-offs, formal technology transfer and capital raising. Ind. Corp. Chang. 2007, 16, 609-640. [CrossRef]

99. Johnson, J.W. A Heuristic Method for Estimating the Relative Weight of Predictor Variables in Multiple Regression. Multivar. Behav. Res. 2000, 35, 1-19. [CrossRef] [PubMed]

100. Johnson, J.W.; Lebreton, J.M. History and Use of Relative Importance Indices in Organizational Research. Organ. Res. Methods 2004, 7, 238-257. [CrossRef]

101. Benneworth, P.; Cunha, J. Universities' contributions to social innovation: Reflections in theory \& practice. Eur. J. Innov. Manag. 2015, 18, 508-527.

102. Lejpras, A. How innovative are spin-offs at later stages of development? Comparing innovativeness of established research spin-offs and otherwise created firms. Small Bus. Econ. 2014, 43, 327-351. [CrossRef]

103. Bolzani, D.; Fini, R.; Grimaldi, R. The Internationalization of Academic Spin-Offs: Evidence from Italy. In Process Approach to Academic Entrepreneurship: Evidence from the Globe; Fini, R., Grimaldi, R., Eds.; World Scientific Publishing: Singapore, 2017; Volume 4, pp. 241-280.

104. Hellmann, T.; Puri, M. Venture Capital and the Professionalization of Start-Up Firms: Empirical Evidence. J. Financ. 2002, 57, 169-197. [CrossRef]

105. Roundy, P.T.; Holzhauer, H.; Dai, Y. Finance or philanthropy? Understanding the motivations and criteria of impact investors. Soc. Responsib. J. 2017, 13, 419-512. [CrossRef]

106. Santos, F.M. A Positive Theory of Social Entrepreneurship. J. Bus. Ethic. 2012, 111, 335-351. [CrossRef]

107. Mc Carthy, B. From fishing and factories to cultural tourism: The role of social entrepreneurs in the construction of a new institutional field. Entrep. Reg. Dev. 2012, 24, 259-282. [CrossRef] 
108. Altinay, L.; Sigala, M.; Waligo, V. Social value creation through tourism enterprise. Tour. Manag. 2016, 54, 404-417. [CrossRef]

109. CYD Report. Fundación Conocimiento y Desarrollo. 2018. Available online: http://informecotec.es/media/ Informe-Cotec_2018_versi\%C3\%B3nweb.pdf (accessed on 22 January 2020).

110. III Innovation Social Perception Survey. Fundación COTEC para la Innovación. [Electronic Version] 2020. Available online: http://informecotec.es/metrica/percepcion-social-de-la-innovacion/ (accessed on 22 January 2020).

111. Wagner, M.; Schaltegger, S.; Hansen, E.G.; Fichter, K. University-linked programmes for sustainable entrepreneurship and regional development: How and with what impact? Small Bus Econ. 2019, 1-18. [CrossRef]

112. McAdam, M.; Marlow, S. A preliminary investigation into networking activities within the university incubator. Int. J. Entrep. Behav. Res. 2008, 14, 219-241. [CrossRef]

113. Rodeiro, P.R.; López, S.F.; González, L.O.; Sandiás, A.R. Factores determinantes de la creación de spin-offs universitarias. Revista Europea Dirección Economía Empresa 2010, 19, 47-68.

114. Van Burg, E.; Romme, A.G.L.; Gilsing, V.A.; Reymen, I.M.M.J.; Romme, G. Creating University Spin-Offs: A Science-Based Design Perspective. J. Prod. Innov. Manag. 2008, 25, 114-128. [CrossRef]

115. Algieri, B.; Aquino, A.; Succurro, M. Technology transfer offices and academic spin-off creation: The case of Italy. J. Technol. Transfer 2013, 38, 382-400. [CrossRef]

116. Rasmussen, E.; Mosey, S.; Wright, M. The Evolution of Entrepreneurial Competencies: A Longitudinal Study of University Spin-Off Venture Emergence. J. Manag. Stud. 2011, 48, 1314-1345. [CrossRef]

117. Swamidass, P.M. University startups as a commercialization alternative: Lessons from three contrasting case studies. J. Technol. Transfer 2013, 38, 788-808. [CrossRef]

118. Saviano, M.; Barile, S.; Farioli, F.; Orecchini, F. Strengthening the science-policy-industry interface for progressing toward sustainability: A systems thinking view. Sustain. Sci. 2019, 14, 1549-1564. [CrossRef]

119. Chiesa, V.; Piccaluga, A. Exploitation and diffusion of public research: The case of academic spin-off companies in Italy. RED Manag. 2000, 30, 329-340.

120. Etzkowitz, H.; Zhou, C. Triple Helix twins: Innovation and sustainability. Sci. Public Policy 2006, 33, 77-83. [CrossRef]

121. Clarysse, B.; Wright, M.; Bruneel, J.; Mahajan, A.; Wright, D. Creating value in ecosystems: Crossing the chasm between knowledge and business ecosystems. Res. Policy 2014, 43, 1164-1176. [CrossRef]

122. Mazzucato, M. The Entrepreneurial State: Debunking Public vs. Private Sector Myths; Anthem Press: London, UK, 2013.

123. Mazzucato, M.; Kattel, R.; Ryan-Collins, J. Challenge-Driven Innovation Policy: Towards a New Policy Toolkit. J. Ind. Competition Trade 2019, 1-17. [CrossRef]

124. COTEC Report. Innovación en España. Fundación COTEC para la Innovación. 2017. Available online: http://cotec.es/media/INFORME-COTEC-2017_versionweb.pdf (accessed on 22 January 2020).

125. Rubio de las Alas-Pumariño, T. Recomendaciones Para Mejorar el Modelo de Transferencia de Tecnología en Las Universidades Españolas; Conferencia de Consejos Sociales de las Universidades Españoles: Las Palmas de Gran Canaria, Spain, 2014.

126. Mazzucato, M. From market fixing to market-creating: A new framework for innovation policy. Ind. Innov. 2016, 23, 140-156. [CrossRef]

127. Siggelkow, N. Persuasion with Case Studies. Acad. Manag. J. 2007, 50, 20-24. [CrossRef]

(C) 2020 by the authors. Licensee MDPI, Basel, Switzerland. This article is an open access article distributed under the terms and conditions of the Creative Commons Attribution (CC BY) license (http://creativecommons.org/licenses/by/4.0/). 